\title{
Luovuus yksilössä ja organisaatiossa
}

\author{
Jussi T. Koski (2001) \\ Luova hierre. Näkökul- \\ mia yksilöiden, ryhmi- \\ en ja organisaatioiden \\ luovuuteen. \\ GUMMERUS
}

\section{"Kaikkitulisitehdänïnyksinkertai- sestikuinmahdollista, muttaei yhtäänyksinkertaisemmin." ALBERTEINSTEIN}

Luovuus on kykyä toimia tarkoituksenmukaisella ja epätavallisella tavalla uusissa, yllättävissä tai epämääräisissä tilanteissa. Luovuus on vaihtoehtojen etsintää ja niiden olemassaolon näkemistä. Se on myös kykyä tuottaa uusia ajatuksia yhdistämällä eri näkökulmia totutusta poikkeavalla tavalla. Luovuus ei siis ole ns. luovuusalojen privilegio. Päinvastoin, taiteilija voi olla jopa huomattavassa osassa tuotantoaan epäluova.

\section{Luovuudesta on lukuisia} teorioita ja selitysmalleja. Panematta niistä toista toisen edelle Jussi T. Koski asettuu vankasti sille kannalle, että tieto, kokemus, erityisosaaminen ja asiantuntijuus kytkeytyvät luovuuteen. Luovuus tarvitsee riittävän monipuolisen ja syvän materian, mistä konstruoitua. Koski viittaa pari kertaa kirjassaan asiantuntijaksi kasvamisen ns. kymmenen vuoden sääntöön. Tärkeää materiaa tässä on vuorovaikutus: monet erinomaiset oivallukset ja ideat syntyvät vuorovaikutuksen ja keskustelun hedelminä. Zygmund Bauman on todennut, että vasta toisten erilaiset ajatukset ja näkemykset "pamauttavat tajunnan liikkeelle" - kiteytys, mikä koskee niin ryhmien ja organisaatioiden kuin yksilöidenkin luovia ajatuksia ja tekoja (Aikuiskasvatus 2001, s. 53). Luova hierre -teoksessa vastaavia ajatuksia on lainattu luovuustutkija Vera John-Steinerilta: luovan kyvyn ja ajattelun kehittyminen tapahtuu ennen muuta ihmisten välillä, ei niinkään yksilöiden "sisällä".

\section{Jussi T. Koski edustaa} luovuuden väylillä kykyä antaa tiedontulvalle hahmo ja napata sieltä uteliaisuudella ja herkkyydellä oman ajattelunsa rakennuspuiksi sellaisia ajatuksia, missä pieneen tilaan kiteytyy suuri määrä kokemusta, viisautta, oivaltamista ja tietoa. Siksi hän siteeraa herkästi ja auktorisoi ajatuksiaan tihein lainauksin. Lainaukset ovat kuin pieniä timantteja tekstissä. Ne antavat kuvattavalle asialle hengen.
Tällainen käsittelytapa lienee välttämätöntäkin sen vuoksi, että Koski on metatutkija. Hänellä ei siis ole luovuuden alueelta omaa alkuperäistutkimusta - "luovia ihmisiä koeputkessa" - vaan hän syntetisoi ja konstruoi. Kosken tutkijanotetta kuvaa se, miten huolellisesti hän on lähteistänyt kaikki lainaamansa kiteytykset, väittämät ja esittelemänsä luovuustutkimukset. Teoksen luotettavuuden näkökulmasta se on myös välttämätöntä, joskin Koskelle itsestäänselvä, luonnollinen työskentelytapa.

\section{Infoähky-käsitteen}

kielenkäyttöömme livauttanut Jussi T. Koski käsittelee myös uusimmassa kirjassaan hallitsematonta tiedontulvaa ja sen puu-duttavaa, luovuuden nujertavaa vaikutusta. Hän tarjoaa kahden aikamme pahan epidemian, infoähkyn ja alinomaisen kiireen, lääkkeiksi tietoista, opeteltua keskittymistä vain itselle tärkeisiin asioihin ja muun määrätietoista karsimista, sekä luovaa laiskuutta ja riittävää lepoa. Kiireettömyys ja väljä aika ovat luovan prosessin välttämättömiä elementtejä. Tehokkuutensa maksimoijia Jussi Koski nimittää uraohjuksiksi. 
Riittävän levon puutteella on mielenkiintoinen kytkös Kalervo Siikalalta napatun lainauksen (s. 50) kautta myös kansanvallan ja maailman tilaan: "Maailmaa hallitaan sumuisin aivoin", on Siikala todennut. "Kansanvalta tarvitsee myös aikaa, kiireetöntä harkintaa, väljyyttä ja näköaloja. Ilman niitä ei synny uutta tieteen, taiteen tai talouden aloilla - saati sitten politiikassa ja yhteiskuntaelämässä." Terveellinen havainto ministereittemme päiväkalentereihin rinnastettuna!

\section{Luova hierre -kirjassa} esitellään valikoiden keskeisimpien luovuustutkijoiden ja -teoreetikkojen ajatuksia. Eniten kirjassa saa huomiota Chicagon yliopiston psykologian ja kasvatustieteen professori Mihaly Csikszentmihaly, joka on kehittänyt systeemisen luovuusteorian ja jonka tunnetuin käsite on optimaalinen kokemus, flow.

\section{Mielenkiintoisinta}

Csikszentmihalyn teorioiden esittelyssä on kenties luovuuden julkisen tunnustamisen keskeisyys. Ei siis riitä, kuten Maslow väittää, että jokin asia on luova henkilön omasta mielestä ja hänen kriteereillään. Idean tai tuotteen on saatava sosiaalinen hyväksyntä. Portinvartijoina toimivan asiantuntijayhteisön on tultava vakuuttuneeksi suoritteen arvosta. Tästä ulkoisen tunnustuksen ehdosta seuraa mielenkiintoinen, ennen muuta taiteista tunnetuksi tullut paradoksi, onhan moni historian luova nero saanut teoksilleen tunnustuksen vasta kauan kuolemansa jälkeen.

Sitä paitsi aitoon luovuuteen kuuluu usein myös anarkisti- nen, asiantuntijayhteisöt sivuuttava elementti.

\section{Mihaly Csikszentmihalyn} korostama asiantuntijayhteisö käyttäytyy erilailla ja sen säätelyvalta vaihtelee riippuen asiantuntemusalan luonteesta. Eriytyneillä ja monimutkaisilla aloilla yhteisö on pieni verrattuna vähemmän eriytyneisiin ja vähemmän kompleksisiin aloihin. Yhteisön elinkaari myös vaihtelee ja huipentuu eräänlaiseen stagnaatioon ja pystyynkuolemiseen. Eikö siis tällaiset asiantuntijayhteisöt toimi luovuuden kampittajina? Niinkin toisinaan. Kuitenkin luova ajatus tai teko vaatii luovaksi muuttuakseen vastakaikua. Koska luovuus elää vuorovaikutuksessa, oppiminen toimimaan jonkin tietyn kentän sääntöjen mukaan lisää Csikszentmihalyn mukaan valtaisasti yksilön luovuuden mahdollisuuksia ja ulottuvuuksia.

\section{Jos asiantuntijayhteisö}

on liian avoin ja hyväksyy kaiken, seurauksena on kritiikittömyys - ja epäluovuus. Asiantuntijayhteisöt toimivat siis myös kulttuureiden olemassaolon takaajina. "Selviytyäkseen kulttuurien tulee eliminoida useimmat uudet ideat. Kulttuurit ovat konservatiivisia, ja hyvästä syystä. Mikään kulttuuri ei voi omaksua kaikkia ihmisten tuottamia uusia ideoita ajautumatta kaaokseen", Mihaly Csikszentmihaly toteaa (s. 75).

\section{Asiantuntijayhteisöjen} itseriittoisuudessa piilee vaara, joka vaikkapa aikuiskasvatustieteilijöiden on syytä itsessään tunnistaa. Yhteisöillä on nimittäin taipumus tuottaa itse omat käsitteistönsä ja kysymyksenasettelunsa ja eristäytyä näin muista asiantuntijakulttuureista.

\section{Luovaa yksilöä Jussi T.}

Koski käsittelee kirjassaan vajaan sadan sivun verran. Jälleen Csikszentmihalyn tutkimukseen nojaten saamme tietää, että luovat ihmiset ovat joko analyyttisia tai intuitiivisia oman oppimansa tiedostajia. Luovaan henkilöön voi liittää erilaisia ominaisuuksia. Yllättävintä tällä listalla on kenties huumori ja nauru, eli kuten Jussi T. Koski tiivistää: ahaa- ja hahaa-elämykset liittyvät toisiinsa likeisesti. Ajatuksen takana on itse asiassa tunneäly-guru, psykologi Daniel Goleman (s. 91-92 sekä 96-97), jonka mukaan nauraminen auttaa ihmisiä ajattelemaan ja assosioimaan vapaammin. Erinomaisen mielenkiintoinen luovan yksilön kymmeneen ominaisuusalueeseen jakautuva analyysi löytyy jälleen Csikszentmihalyltä (s. 94-103).

\section{Intohimo, motivaatio} ja sinnikkyys ovat ominaisuuksista keskeisellä sijalla. Luovien ihmisten toimintatarmo ja intohimo kohdistuu itse asetettuihin tavoitteisiin toisin kuin ihmisten enemmistöllä, joka missä tahansa kulttuurissa käyttää valtaosan ajastaan itsensä ulkopuolelta asetettujen tavoitteiden toteuttamiseen. Tämä on Kosken mukaan yhteiskuntien ja kulttuureiden koossapysymisen kannalta välttämätöntäkin. Mutta toisaalta kulttuurit voivat kehittyä vain, jos mukana on kompromissittomia oman tien kulkijoita.

\section{Yksi luovuuden}

paradokseista liittyy marginaa- 
lisuuden ja sosiaalisuuden väliseen suhteeseen. Vanhemmat esimerkiksi soisivat lastensa olevan sosiaalisia ja sosiaalisesti hyväksyttyjä sekä erilaisia ja luovia. Luovan lapsen ei kuulu olla eristynyt, mutta kuten Csikszentmihaly toteaa, ihminen ei voi olla normaali ja poikkeuksellinen samanaikaisesti.

Csikszentmihaly ei suinkaan ole Kosken ainoa luovuusauktoriteetti, vaikka kylläkin keskeisin ja päätä pidempi muita. Harwardin ja Bostonin yliopistoissa professorina toiminut Howard Gardner tulee kirjassa tutuksi erityisesti neljän luovuustyypin kehittäjänä. Nämä keskenään erilailla toimivat ja profiloituvat tyypit ovat mestari (master), uudistaja (maker), itsetutkija (introspector) ja vaikuttaja (influencer). Heistä nimenomaan uudistajia Gardner pitää äärimmäisen luovina henkilöinä (s. 163-170).

\section{Työyhteisöille}

hyödyllisintä tutkimustietoa ja luovuusteoriaa sisältyy kirjan viimeiseen, ryhmiä ja organisaatioita koskevaan osaan. Yhteisöluovuuden teoreetikkoja ovat ennen muita Bennis ja WardBiederman,Ikujiro

Nonaka, jonka Koski on tavannut itsekin useamman kerran Helsingin kauppakorkeakoulussa työskennellessään, Leonard ja Swap, Robinson jaStern sekäPeterSenge.

\section{Robinson ja Stern}

romuttavat myyttiä sankarillisesta luovasta yksilöstä ja pitävät sen sijaan organisaation kokonaisluovuuden kannalta olennaisempana edistää kaikkien työntekijäin luovuutta. Tämä tapahtuu säätelemällä organisaation luovuuden keskeisiä elementtejä, joita he erittelevät teoksessaan Corporate Creativity (1998).

\section{Yksi aivan keskeisiä}

elementtejä on ihmisten välinen, samassa fyysisessä tilassa tapahtuva vuorovaikutus. Sitä pitävät korvaamattoman tärkeinä niin Robinson \& Stern, Leonard \& Swap kuin Ikujiro Nonaka, jonka käsitteistöä on yhteinen tila, "ba". Se voi olla sauna, kahvihuone, tupakkahuone tai mikä tahansa paikka, joka mahdollistaa työntekijäin kesken tapahtuvan suunnittelemattoman ad hoc -kommunikaation ja lisää onnekkaiden sattumien todennäköisyyttä.

\section{Bennis ja Ward ovat}

tutkineet joukkoa maailman huippuluovia ryhmiä. Kymmeneen ominaisuusryhmään kiteytetty erittely soveltuu malliksi myös tavallisemmallekin oppivalle organisaatiolle. Tavallisia ja käyttökelpoisia työyhteisön luovuutta edistäviä keinoja on mm. työtehtävien kierrättäminen sekä toimenkuvien riittävä rosoisuus. Toimenkuvia ei tule eriyttää liikaa. Aivan keskeinen menestystekijä työyhteisössä on luottamus ja luottamuksellinen ilmapiiri. Charles Handy puhuu jopa luottamusjohtamisesta ja vertaa luottamusta lasiin: kun se kerran rikkoutuu, sitä ei voi koskaan palauttaa entiselleen.

\section{Kosken kirja ottaa}

raikkaasti kantaa luovuuden palkitsemiseen ja bonuksiin organisaatioluovuuden kannustimina. Ihmisen sisäinen motivaatio on keskeinen tekijä. Mitä vähemmän työntekijöiden kehittämisideoita palkitaan materiaalisesti eli motivoidaan ulkoisesti, sitä enemmän esiintyy luovuutta. Ainoa kestävä palkitsija on työntekijän sisäinen toimintamotiivi ja itsensä toteuttamisen tarve sopusoinnussa yhteisen vision ja yhteisten tavoitteiden kanssa.

\section{Mutta mitä kummaa on} luova hierre? Monet luovuustutkijat katsovat, että luovuutta arvostavassa ja vaalivassa organisaatiokulttuurissa erityisesti älyllisten konfliktien tietoinen synnyttäminen on hyväksyttävää ja toivottavaa. Jos tiimien ja ryhmien annetaan itseorganisoitua, 'similarity-attraction' (tottumus pitkäaikaiseen yhdessä työskentelyyn, samantyyppinen koulutus, samantyyppinen ajattelutapa, samantyyppinen työskentelytapa jne.) vetää samankaltaisia ihmisiä tekemään työtä yhdessä. Luovuuden kannalta huonoja ryhmiä ovat siis sellaiset, joissa ei lainkaan esiinny luovaa hierrettä näkemystapojen välillä, ja sellaiset, joissa hierre muuttuu henkilötason jännitteiksi.

\section{Joukossa tyhmyys}

tiivistyy, sanoo vanha sananlasku. Niinkin tietyin reunaehdoin. Siitä Kosken kirja kuitenkin lukijaansa vakuuttaa, että puhuttiinpa miten paljon tahansa luovista ryhmistä, ihmiset synnyttävät enemmän ja parempia ideoita yksin kuin ryhmässä. Mutta sitä ennen tarvitaan useimmiten vuorovaikutusta.

Anneli Kajanto 